\title{
Plágio: para além das questões jurídicas, questões discursivas
}

\author{
Juliane Ferraz Oliveira*
}

\begin{abstract}
Resumo
Este ensaio trata do plágio a partir de uma perspectiva discursiva da linguagem e não sobre aspectos legais e jurídicos que envolvem a questão.

Palavras-chave: Plágio. Linguagem. Discurso.
\end{abstract}

\section{Plagium: in addition to legal issues, discursive issues}

\author{
Juliane Ferraz Oliveira
}

\begin{abstract}
This essay treats the plagiarism from a discursive perspective of language and not on legal and legal aspects that involve the issue.

Keywords: Plagium. Plagiarism. Language. Discourse.
\end{abstract}

* Professora EBTT/Bolsista Capes II. CEFET-MG/PUC Minas. Doutoranda em Letras - Linguística e Língua Portuguesa. 
Imito-os no desejo de me surpreender no processo de invenção do escritor que sou e que, sendo por definição produto de enxertia, não teria sido sozinho.

Silviano Santigo (2021).

Primeiramente, gostaria de dizer que a escrita deste ensaio não carrega a ilusão de fechamento de questão em relação à temática do plágio. Antes disso, o que se propõe é um foco discursivo, ou seja, reflexões que perpassem muito mais pelo âmbito da atividade delinguagem, de parâmetros enunciativos e da mobilização de discursos em relação à produção de textos, do que por aspectos jurídicos de responsabilização civil por apropriação de produção científica ou literária de outrem, ou julgamento moral acerca da escrita alheia.

A temática do plágio é amplamente debatida a partir de vieses jurídicos que dizem respeito à propriedade intelectual de determinada produção. Com o objetivo de compreender o plágio sob a ótica discursiva, neste ensaio, discutir-se-ão algumas concepções de linguagem, de língua e de autoria que atravessam a compreensão desse fenômeno. Vale dizer que as reflexões aqui travadas partirão da tentativa de compreender o plágio tendo como parâmetro as produções acadêmico-científicas textuais.

O campo jurídico compreende o plágio em termos coercitivos, ou seja, de responsabilização de pessoas físicas ou jurídicas pelo uso indevido, ou criminoso, da produção/propriedade intelectual de outrem sem os devidos créditos ou pagamento de direitos autorais, a depender do âmbito do objeto plagiado. Já sob o viés discursivo, quais seriam os elementos que devem ser avaliados em termos de configuração, ou não, como plágio? A cópia integral ou parcial de determinada obra/produção científica configuraria plágio? Esses elementos são quantitativos? Há um nível de plágio que seja aceitável? Mesmo antes de responder a essas perguntas, deixamos claro que um dos pontos principais a ser compreendido é que os parâmetros de compreensão do que seja plágio não devem ser observados somente sob a perspectiva objetiva de contabilização de palavras ou ideias dos autores.

Neste momento, gostaria de dizer que o escopo jurídico e o escopo discursivo não são campos da vida social humana que se contrapõem, nem mesmo se equivalem. A dimensão discursiva perpassa toda prática social humana. As práticas discursivas englobam todas as interações humanas e se configuram como práticas sociais de estabelecimento de relações em

Cadernos CESPUC de Pesquisa. Série Ensaios. n.39, $2^{\circ}$ Sem./2021, p. 78-88. e-ISSN: 2358-3231 (OJS). Recebido em: 26/10/2021. Aceito em: 03/12/2021. 
quaisquer campos de vida do ser. Assim, há práticas discursivas no campo do direito, da política, da religião, das manifestações culturais, da vida cotidiana, etc. Onde há vida humana há prática discursiva que permita as relações entre os seres. Já a dimensão jurídica, que também é discursiva, da vida humana, é criada por meio de convenções sociais e regem as normas de convivência em sociedade naquilo que surge enquanto problemática insolúvel no campo particular/pessoal/individual.

Após essa breve definição, é possível perceber, então, que os discursos constituem as interações humanas como condição mínima para as relações da forma como conhecemos. Falar, então, do plágio sob a lógica prioritária do discurso é assumir que ele não está restrito a uma das formas de organização social humana, mas que ele deve ser compreendido a partir de relações anteriores às subdivisões sociais de áreas, sendo uma questão muito mais relacionada às diversas formas de interação humana como a produção acadêmica, artística, jurídica, política etc.

É preciso dizer que, tanto em relação ao escopo primordialmente discursivo, quanto ao escopo jurídico, a questão do plágio está intrinsecamente ligada à atribuição de autoria, ou seja, quem é o responsável legal e intelectual por certa produção. Compreender certo texto como escrito por determinado autor ou outro determina as implicações judiciais em torno da propriedade daquele produto. Grande parte das questões acerca da temática da autoria giram ao redor do estilo, da forma ou, até mesmo, da originalidade.

Há algumas questões de base quando refletimos sobre plágio: qual a concepção de língua e linguagem subjaz a compreensão daquilo que seja ou não plágio? Quando o uso de palavras alheias é considerado legítimo ou ilegítimo? Naquilo que diz respeito aos Estudos da Linguagem, enquanto campo científico, há bastante tempo linguistas e estudiosos da linguagem, em geral, já compreendem linguagem como atividade, o que significa dizer que ela é um elemento constitutivo das relações humanas e que pode ser manifestada por meio de diversas práticas discursivas. $\mathrm{O}$ que coloca por terra a noção de linguagem como instrumento e/ou ferramenta e isso traz implicações como as compreensões de que há usos certos e errados da linguagem etc. Já o conceito de língua perpassa por compreendê-la como um sistema coletivo que permite a atualização da linguagem. 
A concepção de língua que se adota para discutir aspectos ligados ao plágio pode trazer esclarecimentos importantes. Trabalhar compreendendo que a língua não é uma representação individual realoca a questão da autoria de um texto. Se as palavras não são minhas ou suas, se elas compõem um sistema compartilhado, então, não é que alguém represente a si mesmo ou ao mundo por meio das próprias palavras, antes disso, é a linguagem ea língua que atravessam o sujeito. "A língua vive e evolui historicamente na comunicação verbal concreta, não no sistema linguístico abstrato das formas da língua nem no psiquismo individual dos falantes. " (VOLOCHÍNOV, 2017, p. 127, grifos do autor).

Na perspectiva do Círculo de Bakhtin, a matéria linguística adquire significação em um processo dialógico, assim a língua pressupõe uma postura ativa e responsiva. Desse modo, são constitutivos do sentido o princípio dialógico e a noção de alteridade,todo discurso é fruto de um discurso anterior e prévio de um discurso futuro, constituindo, assim, aspectos de um fio condutor de uma comunicação ininterrupta e solidificada. O que pressupõe o decurso histórico do qual o indivíduo é construtor e construto. A dialogicidade da linguagem possibilita a identificação de ecos, de discursos anteriores, em diferentes práticas enunciativas (VOLOCHÍNOV, 2017).

Quando chegamos ao mundo, ele já era constituído por relações e práticas sociais, bem como de sistemas simbólicos. Assim, aproveitando importante expressão de Bakhtin (1997), nenhum sujeito seria o Adão mítico do discurso, ou seja, não há a possibilidade efetiva de desbravar um mundo discursivo que seja intocado.

O objeto do discurso de um locutor, seja ele qual for, não é objeto do discurso pela primeira vez neste enunciado, e este locutor não é o primeiro a falar dele. O objeto, por assim dizer, já foi falado, controvertido, esclarecido e julgado de diversas maneiras, é o lugar onde se cruzam, se encontram e se separam diferentes pontos de vista, visões do mundo, tendências. Um locutor não é o Adão bíblico, perante objetos virgens, ainda não designados, os quais é o primeiro a nomear. A ideia simplificada que se faz da comunicação, e que é usada como fundamento lógicopsicológico da oração, leva a evocar a imagem desse Adão mítico (BAKHTIN, 1997, p. 319). 
Shineider (1990), em seu livro Ladrões de palavras, potencializa aquilo que tentei argumentar até este momento no texto:

As controvérsias entre escritores ou pensadores acerca do plágio pressupõem que existiria na língua algo como seus próprios bens, o que parecem atestar em sua evidência jurídica os próprios termos da propriedade literária. E, no entanto, uns e outros sabem bem que não há nada para patentear ou para roubar, nada que não pertença a todos: palavras e ideias. Sabem bem, "mas mesmo assim", protestam contra o roubo e reivindicam direitos de propriedade. Sabemos que as palavras são de todos, mas cremos que são só nossas. Não se pode dizer: "minhas próprias palavras" sem nos iludirmos quanto à natureza da linguagem e das palavras que não são mais minhas que de qualquer outro. Ao contrário, posso dizer: minha obra, quando menos porque custou-me tanto e tanto trabalho. A propriedade concerne só à obra, não àquilo de que é feita (SHINEIDER, 1990, p. 391-392).

O leitor desavisado poderia pensar que, já que a língua é um sistema compartilhado por todos, então, nada seria plágio, ou já que tudo está dado e já foi dito, tudo seria plágio. Pedimos que tomem cuidado com as afirmações e conclusões precipitadas, pois a questão do plágio, sob o viés discursivo, além de englobar certa concepção de linguagem e língua, pressupõe, também, certa concepção de contexto e enunciação. Vejamos.

Em poucas palavras, o contexto diz respeito às situações mais ou menos imediatas de determinado discurso, ou seja, tanto questões macro, como campo político, organização social etc., estariam implicadas, bem como situações micro, mais imediatas ao contexto de fala. Já a enunciação, categoria também cara aos Estudos da Linguagem, pode ser caracterizada, de forma simplificada, como o colocar, em funcionamento, a língua por um ato individual de utilização. De acordo com Benveniste (1989), a enunciação supõe a conversão de língua em discurso, e esse seria o objeto dos Estudos da Linguagem: estudar o discurso. Segundo ele,

[...] é o ato mesmo de produzir um enunciado, e não o texto do enunciado, que é nosso objeto. Este ato é o fato do locutor que mobiliza a língua por sua conta. A relação do locutor com a língua determina os caracteres linguísticos da enunciação. Deve-se considerá-la como o fato do locutor, que toma a língua por instrumento, e nos caracteres linguísticos que marcam esta relação (BENVENISTE,1989, p. 82). 
Frente ao que, até agora, fora exposto, frisamos que a língua é um sistema coletivo e compartilhado de formas finitas, já os discursos são formados por enunciados sempre novos e nunca repetíveis, pois cada ato enunciativo é particular.

Pode-se estabelecer um princípio de identidade entre a língua e o discurso, porque no discurso se apagam os limites dialógicos do enunciado, mas jamais se pode confundir língua e comunicação verbal (entendida como comunicação dialógica efetuada mediante enunciados). É possível a identidade absoluta entre duas ou mais orações (sobrepostas, como duas figuras geométricas, elas coincidem). Há mais: qualquer oração, mesmo complexa, dentro do fluxo ilimitado do discurso pode ser repetida ilimitadamente e de uma forma perfeitamente idêntica, mas, enquanto enunciado (ou fragmento de enunciado), nenhuma oração, ainda que constituída de uma única palavra, jamais pode ser repetida, reiterada, duplicada: sempre teremos um novo enunciado (mesmo que em forma de citação) (BAKHTIN, 1997, p. 335).

Percebemos, então, que um enunciado nunca será o mesmo ao ser deslocado, pois um ato enunciativo nunca se repete. Assim, o que os plagiadores fariam seria uma cópia de ordem material, uma cópia de forma, mas nunca uma transposição de ideias, já que a enunciação seria completamente nova. Há, dessa forma, uma ressignificação dos enunciados que são copiados, tornando-os outras enunciações. $\mathrm{O}$ que se quer, aqui, não é compor uma defesa em favor dos plagiadores, mas propor um tensionamento e problematização da compreensão do plágio somente a partir do viés jurídico.

As questões que acercam direitos autorais, de reprodução ou outros, não são parte dessa escrita, a pretensão, neste artigo, é repensar a lógica do plágio como uma lógica do esvaziamento das memórias dos discursos, por meio do silenciamento de outras vozes e da negação de linhas históricas de escritas e discursos que perpassam o objeto de plágio. Assim, a partir do ponto de vista discursivo, é possível debater a questão do plágio como um apagamento da historicidade dos discursos de forma deliberada, ou seja, há uma espécie de silenciamento brusco e não gradual das redes discursivas que compõem determinados discursos. Dessa forma, de maneira proposital, um tipo de censura seria imposta aos discursos. 
Sobre esse silenciamento imposto, Eni Orlandi (2004), antes de chegar ao conceito de plágio propriamente dito, conceitua autoria como um tipo de interpretação. É claro que, se estamos falando de uma estudiosa do campo da Análise de Discurso, devemos compreender interpretação como uma posição frente ao Outro (interdiscurso) e ao outro (interlocutor). Dessa forma, a autoria não pode ser entendida como uma forma de interpretação autônoma, pois há injunções, condições de produções e uma memória institucional que são mobilizados nesse processo. Um autor não interpreta o que quer, como quer, mas se move sob condições ideológicas e discursivas específicas.

É importante dizer que Orlandi (2004), ao descrever o conceito de autoria sob a perspectiva da interpretação, considera que, a partir de parâmetros ideológicos e discursivos, o processo de construção textual é marcado pela repetição em três pontos: repetição empírica, que não historiciza; repetição formal, também não historiciza; e a repetição histórica, que inscreve o dizer no repetível da memória constitutiva, o interdiscurso. O repetível é, nesse contexto, compreendido enquanto memória discursiva histórica.

A inscrição do dizer no repetível histórico (interdiscurso) é que traz para a questão do autor a relação com a interpretação, pois o sentido que não se historiciza é ininteligível, ininterpretável, incompreensível. Isto nos leva a afirmar que a constituição do autor supõe a repetição, logo, como estamos procurando mostrar, a interpretação. Mais extensamente podemos mesmo afirmar que o dizível é o repetível, ou melhor, tem como condição a repetição. Não é porque é o mesmo, mas é o que é passível de interpretação: o que é passível de ser repetido, efeito de pré-construído (já-dito) na relação com o interdiscurso. (ORLANDI, 2004, p. 70-71).

Um outro aspecto importante dos conceitos de autoria e interpretação é o de que o silenciamento é um processo natural, um aspecto histórico e, assim, constitutivo. Por meio da incompletude da linguagem, ou seja, dos silêncios históricos e graduais, é que a autora deslinda a questão da interpretação como movimento. Para ela,

[t]oda fala resulta assim de um efeito de sustentação no já dito que, por sua vez, 
só funciona quando as vozes que se poderiam identificar em cada formulação particular se apagam e trazem o sentido para o regime do anonimato e da universalidade. Ilusão de que o sentido nasce ali, não tem história. Esse é um silenciamento necessário, inconsciente, constitutivo para que o sujeito estabeleça sua posição, o lugar de seu dizer possível. [...]

Desse silencio, que é um silêncio (constitutivo) sobre a interpretação (ela se apaga no momento mesmo em que se dá), resulta a ilusão que permite ao sujeito experimentar os "seus" sentidos. Esta seria a "censura original", radical, a que torna possível o discurso do/no sujeito (ORLANDI, 2004, p. 71-72).

Só que há certas condições em que há uma ruptura no movimento da interpretação, segundo a estudiosa, seria este o caso do plágio. Vejamos:

O plágio, por seu lado, é um subproduto desse silenciamento necessário. Mas ele tem suas particularidades, ao se dar no nível da autoria: o plagiador silencia seu trajeto, ela cala a voz do outro que ele retoma. Não é um silenciamento necessário mas imposto, uma forma de censura [...] entre o dito e o não-dito é irremediável que haja um espaço de interpretação que não se fecha. Lugar de equívocos, de deslocamentos, de debates, de possíveis. O plagiador, na verdade, nega essa possibilidade pois ao reduzir o movimento dos sentidos, acentua a impressão de realidade do pensamento (ilusão referencial que produz o sentimento de que há uma relação natural entre as palavras e as coisas) e a do sujeito como origem de seu dizer (ilusão de que os sentidos nascem nele). Ao censurar, o plagiador se fecha narcisicamente na vontade que o dizer comece e acabe nele mesmo e não se deixa atravessar nem atravessa outros discursos. O que resulta na asfixia do sujeito e na rarefação dos sentidos. Ilude-se com a existência da ideia absoluta e "esquece" que todo dizer é necessariamente incompleto (assim como o sujeito) (ORLANDI, 2004, p. 72-73).

Considerando o plágio a partir de aspectos discursivos, procuramos compreender o que significa, no âmbito do discurso, plagiar a produção do outro. Concordamos com Orlandi (2004) naquilo que respeita ao plagiador propositalmente silenciar os percursos históricos dos discursos. Isso significa dizer que, de forma, deliberada, há um corte abrupto ao invés 
de um processo mais lento e gradual de esquecimento e silenciamento de determinadas vozes e redes discursivas de determinados textos.

Esse silenciamento brusco provoca uma ilusão de que o que se escreve não está fincado em certo contexto e não compõe certa enunciação. É como se houvesse uma espécie de higienização de elementos mínimos constitutivos das redes discursivas. Tira-se tempo-espaço-contextomacro-micro e considera-se a escrita de um texto como ocupante de um vácuo espaço-temporal e contextual. O que demonstra certa concepção de linguagem e de língua adotada por indivíduos que insistem em copiar sem construir uma linha temporal dos discursos que vieram, antes, apagando a memória que constitui os discursos que são objeto de plágio. O plagiador, então, constrói uma ilusão de que, por "controlar as palavras", o sentido nasce de si, de que não há um processo histórico marcado pela ideologia subjacente a todo e qualquer discurso.

Se a língua é um sistema coletivo compartilhado, portanto, dialógico, por que não reconhecer aqueles que vieram antes, ao invés de se propor como fonte e origem do saber e significado? É claro que há questões éticas por traz disso, mas há, também, uma dose de ignorância quanto às concepções de linguagem e língua estudadas há bastante tempo no âmbito dos Estudos Linguísticos, bem como um certo nível de inocência em relação ao controle e origem dos sentidos.

Por fim, é preciso dizer que, em uma perspectiva discursiva, o plágio deve ser compreendido como um movimento de censura deliberada em relação a redes discursivas que compõem que o objeto plagiado. Seria, assim, uma tentativa de apagamento de processos históricos que atravessam todo e qualquer discurso. Dessa maneira, o plágio silencia vozes e impõe à força um apagamento brusco das memórias dos textos plagiados. Nesse sentido, o plágio constitui um movimento violento em relação à atualização do imaginário social, pois o plagiador constrói para si uma espécie de vácuo discursivo histórico-social. 


\section{Referências}

BAKHTIN, Mikhail. Estética da criação verbal. Tradução de Maria Emsantina Galvão G. Pereira, São Paulo: Martins Fontes, 1997.

BENVENISTE, E. Tradução de Eduardo Guimarães. São Paulo: Pontes, 1989.

BENVENISTE, E. Vista dolhos sobre o desenvolvimento da linguística. In: Problemas de Lingüística Geral I. (Tradução Maria da Glória Novak e Maria Luiza Neri). Campinas, S.P.: Pontes, 1991, p. 19-33.

ORLANDI, E. P. Interpretação: autoria, leitura e efeitos do trabalho simbólico. São Paulo: Pontes, 2004.

SHINEIDER, M. Ladrões de palavras. Campinas: Editora da UNICAMP, 1990.

SANTIAGO, Silviano. Menino sem passado. São Paulo: Companhia das Letras, 2021.

VOLÓCHINOV, V. N. Relação entre a infraestrutura e as superestruturas. In: Marxismo e Filosofia da Linguagem: problemas fundamentais do método sociológico. Tradução, notas e glossário de Sheila Grillo e Ekaterina Vólvoka Américo. São Paulo: Editora 34, 2017. 